\title{
Study on Difference between Regional Policy Intensity and Regional Financial Development
}

\author{
Fangqin Chen \\ College of Science and Technology \\ Nanchang University \\ Nanchang, China 330029
}

\author{
Mengxing Chen \\ Nanchang Central Branch \\ People 's Bank of China \\ Nanchang, China 330006
}

\begin{abstract}
As the main body of institutional change and innovation in the region, the difference of the local government's policy action should be an important institutional variable to explain the difference of regional financial development. Starting from organizing the forming mechanism of difference between the local government's policy action and regional financial development, this paper puts forward some suggestions on how to optimize the local government's policy action and promote the benign interaction of regional economy and finance on the basis of analyzing the positive and negative effects of local government's policy action on regional financial development.
\end{abstract}

Keywords-regional policy; regional financial development; economic growth; difference

\section{INTRODUCTION}

With the continuous process of economic marketization and the continuous improvement of China's financial system, the financial industry is playing an increasingly prominent role of the national economy as the core of modern economy. However, from the development status, China's financial development has shown a state of regional imbalance. On the basis of organizing the theory of government behavior and financial development as well as regional economic growth at home and abroad, this paper impersonally and fairly treats the relationship between public policy of local government and regional financial development, analyzes the positive effect of various public policies on financial development and even economic growth, identifies the problems of local government's behavior in regional financial development, and puts forward corresponding countermeasures and suggestions to achieve the goal of optimizing government behavior, maintaining the healthy and orderly development of regional finance.

\section{THE FORMING MECHANISM OF DIFFERENCE BETWEEN} THE LOCAL GOVERNMENT'S POLICY ACTION AND REGIONAL FINANCIAL DEVELOPMENT

As for the regional financial difference, in addition to physical and geographical condition, economic base, historical and cultural environment and other factors, as the main body of regional institutional change and innovation, the difference of the local government' s policy action should be an important institutional variable to explain the difference of regional financial development. In fact, since the reform and opening up, under China's specific institutional arrangements, including specific economic decentralization, political centralization and government-led economic reform, for political interest under the game of political promotion and economic interest under financial decentralization represented by the system of dividing revenue and expenditure between the central and local government, he local governments have been showing up as the first action group of institutional change and innovation in the region. The logical relationship between the difference of local government's policy action and regional financial development is mainly manifested in two aspects: on the one hand, through institutional innovation, the local government speeds up regional economic marketization process, promotes difference in regional economic development competitiveness and leads to difference in regional financial development. On the other hand, it is reflected in the difference of regional financial ecological construction. The difference of regional credit environment and construction of law environment will inevitably lead to the difference of regional financial ecological quality and affect the development of regional finance. Fig.1 is the logical relationship between local government's policy action and regional financial development.

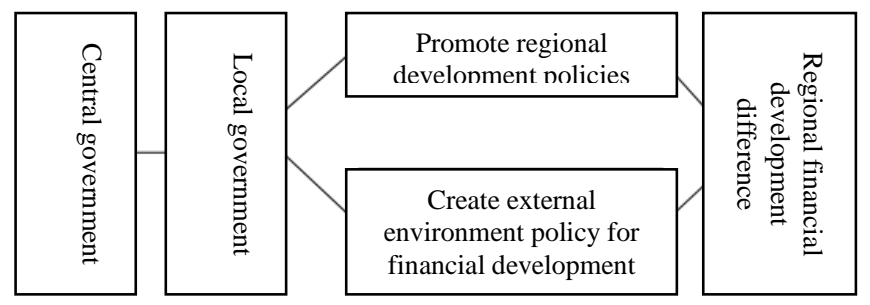

Fig. 1. The logical relationship between local government's policy action and regional financial development

*Fund Project: 2016 Humanities and Social Sciences Subject of Universities in Jiangxi: Path Choice of Industrial Low-carbon Development in Ganjiang New District - Based on the perspective of the structural reform of supply side(JJ162016). 


\section{THE MAIN POLICY ACTION MODEL OF LOCAL GOVERNMENT IN REGIONAL FINANCIAL DEVELOPMENT}

\section{A. Strive for More Financial Resource}

With the deepening of decentralization reform and the implementation of the fiscal system reform with "division of revenue and expenditure between the central and local governments", the local government has been given a relatively independent economic interest in the whole economic system and become the "quasi-market subject" in fact. In the situation where the fiscal capacity declines, and the financing ability pf financial system from top to bottom grows, in fact there is a "strong financial, weak fiscal" pattern in China. Local government, as rational-economic man, in the case of asymmetry of power and financial power and general capital bottleneck, in order to develop the local economy, expand tax source, maintain social stability, and guarantee employment and performance requirement, through explicit or invisible intervention to exert influence on bank credit business, strives for banks and other financial institutions' financial resources support, which in fact is a necessary rational choice.

\section{B. Strengthen the Construction of Local Financial Organization System}

Changes in the financial system give financial institutions the "policy endowment" to accumulate and allocate funds, and one financial institution more is equivalent to one way more for the region to strive for fund. Therefore, the high enthusiasm manifested by local government in the construction of financial institutions generally increases the construction effort of local financial institutions, especially urban commercial banks and rural credit cooperatives. In recent years, through financial injection, capital restructuring, capital increase and the introduction of domestic and foreign strategic investors, etc., based on the original urban credit cooperatives or local financial services, a large number of urban commercial banks, rural commercial banks and village banks spring up.

\section{Use Capital Market for Direct Financing}

With the continuous improvement of laws and regulations and supervision system in China's securities market, and the continuous improvement of the market size of the stock and bond market and financing ability, the capital market has become the second important financing way of Chinese enterprises following bank credit. Local government incorporates building modern enterprise system, enterprise listing and bond issuing, expanding the scale of direct financing into the objective function of local economic development, and give policy support.

\section{Promote the Construction of Regional Financial Center}

Under the guidance of financial development theory, in line with the purpose of constructing investment and financing platform, improving financial service, and vigorously developing modern high-level service industry, a number of central and provincial capital cities have put forward the development plan of constructing financial center. In addition to Shanghai and Beijing which have proposed to establish the international financial center and financial center with the international influence adapted to China's economic strength and the international status of RMB, Shenzhen, Tianjin, Hangzhou, Chongqing, Hefei, Zhengzhou and other cities have successively proposed the strategic planning of constructing regional finance center and regional international financial center city.

\section{EMPIRICAL ANALYSIS}

\section{A. The Selection of Explanatory Variable Indicator}

1) Non-performing loan ratio: The lower the nonperforming loan ratio is, the better effects of the local government's work in local financial ecological environment or the policy measure it launches, with reference to the relevant research, this paper takes the non-performing loan ratio as an important indicator to measure the regional financial ecological environment.

2) The level of government support: Local government increases the size of deposits and loans of financial institutions in the region by increasing fiscal investment, and uses its own influence to ask for financial resources from the central financial sector to influence the development of regional finance. This paper uses the proportion of the local government's fiscal expenditure in GDP that year to represent the level of government support.

3) The level of marketization: The local government provides a perfect market mechanism to optimize the efficiency of resource allocation, improve the productivity of the department and the investment rate of return of the project, stimulate funds in other regions to flow to this region and promote regional financial development. This paper presents the pattern of ownership with the ratio of the main business income of the scale above industrial enterprises minus the main business income of the state-owned and state-owned holding enterprises to the main business income of the scale above industrial enterprises. The higher the proportion of the main business income of non-state-owned and non-statecontrolled enterprises account for, the higher the proportion of non-state-owned enterprises in the ownership structure of the region, the higher the level of marketization in the region.

4) The level of industrial structure: The technological and institutional innovation of enterprises brought about by the improvement of the industrial structure level has resulted in a larger and diversified financial demand, which has promoted the continuous development of regional financial structure and scale to meet the upgrading of industrial structure. This paper presents the level of industrial structure with the proportion of of the second and third industries' output value in GDP, to analyze the impact of industrial structure level on financial development.

5) The level of urbanization: The level of urbanization is ultimately reflected as the ability of local governments to provide public resources and services. This paper presents the level of urbanization with the ratio of urban population to the total population in the region, that is, the rate of urbanization. 


\section{B. Selection of the Explained Variable}

Banking industry has a central role in China's financial system, and the indirect financing with the main form of providing loans with financial intermediary is the major means of financing in China, and the Financial Interrelations Ratio (FIR) defined by the ratio of the outstanding of deposits of financial institutions at the end of year and national income (GDP) can measure the level of financial development in China to a greater extent, therefore, this paper will measure the level of financial development in China's various regions with FIR as an indicator.

\section{Data Sources}

This paper chooses the financial data such as nonperforming loan ratio, government expenditure, non-stateowned and state-owned holding enterprises, the income of the second and third industries, the urbanization rate and the outstanding of deposits and loans of financial institutions at the end of year in the 31 provinces in 2001-2014. All the data comes from 2015 "China Statistical Yearbook", "China Financial Yearbook" and "China Regional Financial Operation Report".

\section{Model Construction}

$\ln F I R_{\text {IIt }}=\beta_{1} \ln G O V_{\text {it }}+\beta_{2} \ln M A R K E T_{\text {it }}+\beta_{3} \ln P_{\text {it }}+\beta_{4} \ln B L R_{\text {it }}+\beta_{5} \ln U R_{\text {tr }}+\varepsilon_{\text {it }}$

The explained variables is FIR, Financial Interrelations Ratio presents the financial development level of various provinces; the explanatory variable GOV, presents the level of government support; MARKET, proportion of ownership, presents the level of marketization; $\mathrm{P}$, the proportion of the second and third output value in GDP, presents the level of industrial structure; BLR, the level of non-performing loan ratio, presents the financial ecological environment; UR, the level of urbanization

\section{E. Unit Root Test}

In order to avoid the phenomenon of "pseudo-regression", the smoothness of the variables should be checked before the panel data regression. The method to verify the sequence stability of the panel is the same as the method to check the time series, which are both unit root test. There are many methods of unit root test, and this paper uses LL test (for the unit root test of the same root) and IPS test to test the unit root. If the two tests are inconsistent, it indicates that the variable is not smooth, and the differential unit root test is continued until it is stable. The first-order difference LL test statistic and IPS test statistics of panel data involved in the paper have passed the $1 \%$ significance level test, indicating that the first-order difference of all variables is a stable sequence, and the order of the unit roots of all variables is connected so that the panel data regression can be conducted to the variables involved.

Regression (1) in the table takes the non-performing loan ratio (lnBLR) and the urbanization level (lnUR) as explanatory variables. The results show that there is a negative correlation between the non-performing loan ratio and the financial correlation ratio. The higher the non-performing loan ratio, the worse the financial policy environment created by the local government, and the slower the regional financial development.
The level of urbanization has a positive correlation with the level of financial development. For every $1 \%$ increase in the level of urbanization, there is a $0.25 \%$ increase in the level of financial development, which shows that the government's improvement of the quality of public services attracts population and a large amount of foreign capital to flow to this region, and further increase the financial resources of this region.

TABLE I. TEST RESULT

\begin{tabular}{|c|c|c|c|c|}
\hline \multirow{2}{*}{$\begin{array}{l}\text { Variables and } \\
\text { test statistics }\end{array}$} & \multicolumn{2}{|c|}{ Horizontal statistics } & \multicolumn{2}{|c|}{ First-order difference } \\
\hline & LL check & IPS check & LL check & IPS check \\
\hline $\operatorname{lnFIR}$ & 3.071 & -0.868 & $\overline{14.109 * * *}$ & $-8.495 * * *$ \\
\hline $\operatorname{lnGOV}$ & 1.361 & 6.022 & $-9.841 * * *$ & $-7.593 * * *$ \\
\hline lnMARKET & 7.402 & 2.504 & $-5.133 * * *$ & $-3.614 * * *$ \\
\hline $\ln \mathrm{P}$ & $-5.340 * *$ & 1.371 & $\begin{array}{l}- \\
24.767 * * *\end{array}$ & $-9.200 * * *$ \\
\hline $\operatorname{lnBLR}$ & 12.549 & 4.587 & $-9,832 * * *$ & $-4.647 * * *$ \\
\hline $\operatorname{lnUR}$ & $-9.532 * * *$ & 3.638 & $-7.658 * * *$ & $-5.579 * * *$ \\
\hline
\end{tabular}

${ }^{\text {a. }}$ Note: * refers to the statistical significance on $10 \%$ significance level; ** refers to the statistical significance on $5 \%$; *** refers to the statistical significance on $1 \%$.

TABLE II. REGRESSION RESULT

\begin{tabular}{|c|c|c|c|c|c|}
\hline \multirow{2}{*}{$\begin{array}{c}\text { Explana } \\
\text { tory } \\
\text { variable }\end{array}$} & \multicolumn{5}{|c|}{ Explained variable: $\operatorname{lnFIR}$} \\
\hline & 1 & 2 & 3 & 4 & 5 \\
\hline Constant & $\begin{array}{l}4.337 * * * \\
(8.654)\end{array}$ & $\begin{array}{l}4.185^{* * * *} \\
(8.413)\end{array}$ & $\begin{array}{l}4.402 * * * \\
(8.661)\end{array}$ & $\begin{array}{l}9.343 * * * \\
(10.509)\end{array}$ & $\begin{array}{l}4,849 * \\
* * \\
(10.943 \\
) \\
\end{array}$ \\
\hline $\operatorname{lnGOV}$ & & $\begin{array}{l}0.163 * * * \\
(3.133)\end{array}$ & & & $\begin{array}{l}0.157 * \\
* * \\
(3.556)\end{array}$ \\
\hline $\begin{array}{l}\text { lnMAR } \\
\text { KET }\end{array}$ & & & $\begin{array}{l}0.226 * * * \\
(3.787)\end{array}$ & & $\begin{array}{l}0.249 * \\
* * \\
(3.799)\end{array}$ \\
\hline $\ln \mathrm{P}$ & & & & $\begin{array}{l}0.828 * * * \\
(10.909 \\
\text { ( } 10\end{array}$ & $\begin{array}{l}0.847 * \\
* * \\
(11.0 \\
88)\end{array}$ \\
\hline $\operatorname{lnBLR}$ & $\begin{array}{l}-0.334 * * * \\
(-6.794)\end{array}$ & $\begin{array}{l}-0.293 * * * \\
(-5.878)\end{array}$ & $\begin{array}{l}- \\
0.345 * * * \\
(-6.779)\end{array}$ & $\begin{array}{l}-0.358 * * * \\
(-9.395)\end{array}$ & $\begin{array}{l}- \\
0.346 * \\
* * \\
(- \\
7.625)\end{array}$ \\
\hline $\operatorname{lnUR}$ & $\begin{array}{l}0.248 * * * \\
(3.258)\end{array}$ & $\begin{array}{l}0.208 * * * \\
(2.953)\end{array}$ & $\begin{array}{l}0.239 * * * \\
(3.305)\end{array}$ & $\begin{array}{l}0.229 * * * \\
(3.652)\end{array}$ & $\begin{array}{l}0.188 * \\
* * \\
(3.035)\end{array}$ \\
\hline$R^{2}$ & 0.92 & 0.92 & 0.92 & 0.92 & 0.95 \\
\hline $\begin{array}{l}\mathrm{F} \\
\text { statistic }\end{array}$ & 114.077 & 114.398 & 111.674 & 148.685 & 441.21 \\
\hline Kao & $-3.095 * * *$ & $-3.656 * * *$ & $-\overline{3.096 * * *}$ & $-5.052 * *$ & $\begin{array}{l}- \\
4.95 * * \\
*\end{array}$ \\
\hline
\end{tabular}

b. Note: * refers to the statistical significance on $10 \%$ significance level; ** refers to the statistical significance on $5 \%$; *** refers to the statistical significance on $1 \%,()$ is T statistic.

Regression (2) in the table takes the level of government support (lnGOV) as an explanatory variable, and the nonperforming loan ratio (lnBLR) and urbanization level (lnUR) as control variables for the measurement model. The results 
show that for every $1 \%$ increase in government investment, the financial development improves $0.16 \%$. It indicates that the government guides the direction of infrastructure and investment, and promotes regional financial development through appropriate intervention in social production and distribution.

Regression (3) in the table adds the marketization level (lnMARKET) as an explanatory variable, and adds the nonperforming loan ratio (lnBLR) and the urbanization level (lnUR) as control variables for the measurement model. The regression results show that the government's efforts to improve the ownership mechanism, develop the private economy and promote the marketization level have a positive effect on the regional financial development.

Regression (4) in the table adds the level of industrial structure (LnP) as an explanatory variable, and adds nonperforming loan ratio (lnBLR) and the urbanization level (lnUR), and the results show that the for each $1 \%$ increase in regression coefficient of the level of industrial structure development, the financial development level increases $0.829 \%$, with significant effect. It indicates that the government can promote regional financial development with adjustment of industrial structure,

Regression (5) in the table selects all explanatory variables and control variables for regression, it it's found that the regression coefficients of all variables pass the significance level of test, and the relationship does not change significantly, indicating that the explanatory variables indeed have influence on the explained variables.

The above empirical results show that the local government's policy action will have a positive or negative impact on the development of regional finance to a certain extent. As far as Jiangxi Province is concerned, the marketization index of 2015 was 6.79 in Jiangxi, just above the national average; in 2014 , the proportion of private holding enterprises in Jiangxi Province was $81.19 \%$ in the total number of enterprises, nearly $4 \%$ below the national average, indicating that the government needs to be further strengthened in cultivating the main body of economic development and activating the enthusiasm of the market. In 2015, the nonperforming loan ratio of financial institutions in the province was $2.45 \%$, with 0.78 percentage points above the national average level, which indicated that the external environment of Jiangxi's financial development had yet to be further optimized. In 2014 the province's primary industry added value accounted for $10.72 \%$ of GDP, 1.52 percentage points higher than the national average, indicating that the industrial structure is not reasonable. In 2014, the province's urban population accounted for $50.22 \%, 2.55$ percentage points lower than the national average, indicating that the government in the provision of quality public goods, attracting more population to the central town gathering also need to work. In 2014, Jiangxi Province, the provincial revenue in 31 provinces and cities ranked 18th, the total financial volume is relatively small, docking financial support is limited. Overall, the local government of Jiangxi Province to promote regional financial development policy strength has yet to be improved.

\section{CONCLUSION}

Suggestions on Promoting the Regional Financial Development Policy of Jiangxi Province.

\section{A. To Optimize the Regional Economic Structure, the} Establishment of the Endogenous Mechanism of Financial Development

Optimize the investment and business environment within the jurisdiction, and create a good entrepreneurial atmosphere, and actively introduce a market competition mechanism to encourage private capital and foreign investment for business activities in the area, and carefully cultivate a large number of dynamic, competitive and competitive sense of diversification Market players, for the regional financial development to create a good micro-market players. Continue to accelerate the transformation and upgrading of traditional industries and gradient transfer, and vigorously develop high-tech industries, advanced equipment manufacturing industry, modern information, logistics, finance and other senior services. Seize the favorable opportunity of national policy support, accelerate the development of Ganjiang New Area, Gannan and other former Central Soviet Area, to guide the population to the central region of the city gathered to cultivate new economic growth pole.

\section{B. To Strengthen the Construction of Local Credit System, to Create A Good Financial and Ecological Environment}

Local governments should proceed from themselves, eliminate all kinds of institutional and institutional obstacles contrary to the principles of the market, promote the integrity of government, responsible government, the rule of law government, and continuously improve the government's integrity and policy implementation. To create a good social credit atmosphere as their responsibility, the comprehensive use of legal, economic, publicity and education, public opinion and other means to strengthen the positive guidance, and urge enterprises to improve the financial system, strengthen information disclosure, enhance corporate debt service awareness and credit The Optimize the financial and judicial environment, local governments should further establish and improve the local financial laws and regulations, to explore the establishment of judicial departments and financial institutions linkage mechanism, increase the various financial default cases and enterprises to crack down on debt action, improve financial success The rate of execution of the case, put an end to the tendency of judicial localization, and earnestly safeguarding financial claims.

\section{To Strengthen Policy Coordination and Safeguard Regional Financial Security}

Local governments should cooperate with the central bank's branches to establish and improve the local financial regulatory coordination mechanism, implement the supervision of various types of institutions whose establishment is locally approval, and prevent regulatory arbitrage and gap. It shall build the communication and cooperation platform of government, financial institutions and regulatory departments in forms like joint conference system of economic and financial stable situation analysis, and timely grasp the risk 
situation of financial institutions within the jurisdiction. After finding the hidden dangers, they shall together study the problem of financial stability to be solved, and achieve the effective solution to local economic development strategy and the national financial policy.

\section{To Increase Local Finance'S Support for Financial Development, Improve Regional Financial Organization System}

Through financial subsidies, tax rebates, land leasing and other aspects of the preferential measures, the government actively encourages banks, insurance, securities, fund companies and other financial institutions in the jurisdiction to establish branches, and develops financial companies, auditing, accounting and law firms and other intermediary advisory bodies. It actively promotes the establishment of new rural financial organizations such as village banks and improves the rural financial organization system.

\section{REFERENCES}

[1] Wu Haihua, Zhang Xu. Economic growth- industrial structure-financial development [J] Economic Theory and Economic Management, 2001, (5): 6-11.

[2] Fan Fangzhi, Zhang Lijun. Research on the Change of Financial Structure and the Upgrading of Industrial Structure in China [J]. Finance Research, 2003, (11): 36-48.

[3] Hui Xiaofeng, Shen Jing. Empirical Study and Comparison on the Relation between Financial Development and Industrial Structure Upgrading in the Three provinces in Northeast China [J]. Journal of Harbin Institute of Technology (Social Science Edition), 2006, (3): 8791

[4] Ma Zhili, Zhou Xiangyu. Empirical Study on the Relationship between Financial Development and Industrial Structure Upgrading in China [J]. Shanghai Finance, 2008, (2): 18-21.

[5] Liu Renwu. Empirical Study on Theory of Regional Financial Structure and Financial Development [M]. Economic Management Press, 2003: 55-64.

[6] Cao Guangjing. Status and Role ofLocal Government in Financial Market[J]. Management Observation, 2013 (28).

[7] Dong Shuo. Evaluation and Research on Financial Ecological Environment in Shandong Province Based on AHP-DEA [D]. Shandong University of Finance and Economics 2016. 